\title{
IAG Newsletter
}

\author{
Gyula Tóth
}

Published online: 6 February 2010

(C) Springer-Verlag 2010

The IAG Newsletter is under the editorial responsibility of the Communication and Outreach Branch (COB) of the IAG. It is an open forum and contributors are welcome to send material (preferably in electronic form) to the IAG $\mathrm{COB}$ (newsletter@iag-aig.org). These contributions should complement information sent by IAG officials or by IAG symposia organizers (reports and announcements). The IAG Newsletter is published monthly. It is available in different formats from the IAG new internet site: http://www.iag-aig. org.

Each IAG Newsletter includes several of the following topics:

I. General information

II. Reports of IAG symposia

III. Reports by commissions, special commissions or study groups

IV. Symposia announcements

V. Book reviews

VI. Fast bibliography

Books for review are the responsibility of:

C. C. Tscherning

Department of Geophysics

University of Copenhagen

Copenhagen, Denmark

Fax: +45 35365357

E-mail: cct@gfy.ku.dk

G. Tóth $(\varangle)$

IAG Communication and Outreach Branch,

MTA-BME Research Group for Physical Geodesy and Geodynamics, Department of Geodesy and Surveying,

Budapest University of Technology and Economics,

1521 Budapest, Hungary

e-mail: newsletter@iag-aig.org

URL: http://www.iag-aig.org/

\section{General announcements}

\subsection{New chairperson of ILRS}

The ILRS Governing Board has elected Dr. Graham Appleby to succeed the late Werner Gurtner as its chair. He will lead the board for the remainder of Werner's term, through 2010. Dr. Appleby is head of the UK's Natural Environment Research Council (NERC) Space Geodesy Facility in Herstmonceux and has been a key figure in SLR activities and the ILRS for more than 10 years. He was involved in software development for the Herstmonceux laser ranger from the early 1980s, following which he gained a PhD in SLR analyses from the University of Aston. During the last 10 years he has been a coordinator of the ILRS Signal Processing Working Group and co-coordinator of the Analysis WG, and is currently leading the Missions WG.

Carey Noll Secretary, ILRS Central Bureau 